\title{
A New Genus of Bulgarian Cave Spiders \\ (Protoleptoneta bulgarica n.g., n. sp., Leptonetidae)
}

by

\section{Christo DELTSHEV*}

Drensky (1931) reports 41 species from 9 families of spiders inhabiting Bulgarian caves. The family Leptonetidae was not indicated in his list. Other investigations conducted intensively by Bulgarian biospeleologists, did not establish the presence of this family, although the geographical position indicated, that it might exist in Bulgaria. Two years ago, my colleague $P$. Beron gave me a collection including $1 \delta^{*}$ representative of Leptonetidae, collected in "Dupna mogila" cave, the Balkan moutains. Later, 1 \& and 1 o specimens were found in "Besimenna 22" cave near the village of Karlukovo, Bulgaria. This provided an opportunity for a more profound study which resulted in the establishment of a new genus, which I call Protoleptoneta.

I am especially obliged to Dr. Brignoli of Rome for his advice and to Dr. Hubert of Paris for sending of comparative material.

\section{PROTOLEPTONETA n.g.}

Typus generis: Protoleptoneta bulgarica n. sp.

Cephalothorax with a median dark line.

Eyes, well developed, surrounded by a black strip.

Chelicerae, armed with 7 teeth on anterior margin, equable and equidistant. Posterior row with 6 denticles.

Femora on male palp spineless. Patellar spine not very strong. Tibia with a few small spines. Tarsus nearly long as tibia. Near the top there is a thicker spot on the ectal side provided with a strong spine, longer than others. There is a shallow depression, in front of this thicker spot.

Bulbus is placed in the basis of tarsus and armed with elongated stylet.

The genus Protoleptoneta unites features of the genera Leptoneta and Paraleptoneta but there are many differences, which divide it from these genera.

The genus Protoleptoneta differs from genus Leptoneta as follows:

1. The tarsus of the male palp does not possess the characteristic apophysa of Leptoneta.

* Zoological Institute and Museum, 1 Boulevard Ruski, Sofia, Bulgaria. 
2. The tarsus is less depressed and does not branch out.

3. The teeth of chelicerae are equable and equidistant.

The genus Protoleptoneta differs from the genus Paraleptoneta as follows:

1. The femora of male palp is spineless.

2. Near the top of tarsus, on the ectal side, there is a thicker spot, provided with a strong spine longer than others.

3. The tarsus is more depressed.

In Protoleptoneta we must place the species Paraleptoneta italica which possess all features and differences, differentiating Protoleptoneta from Leptoneta and Paraleptoneta. The view point of Komatsu (1970), that $P$. italica belongs to Leptoneta is not convincing, because it is very different from typical representatives of Leptoneta (Brignoli 1971).

\section{PROTOLEPTONETA BULGARICA n. sp.}

Description of male.

Total length $-2.01 \mathrm{~mm}$. Cephalothorax, length $-0.82 \mathrm{~mm}$, wide -0.73 , pale yellow, convexed with a toracal furrow.

Eyes (fig. 1) well developed, surrounded with a black strip. Anterior eyes almost equable, posterior nearly 1 diam. from anteriors and distant from anterior laterals ca. 1 diam. from anteriors.

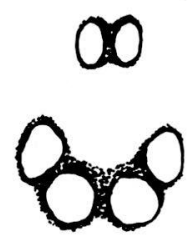

Fig. 1. Eyes ( $0^{\star}$ from in front).

Chelicerae, length $-0.56 \mathrm{~mm}$, wide $-0.21 \mathrm{~mm}$, armed with 7 teeth, equable and equidistant. Posterior row with 6 denticles.

Sternum, length $-0.64 \mathrm{~mm}$, wide $-0.54 \mathrm{~mm}$.

Abdomen, length $-1.10 \mathrm{~mm}$, wide $-0.82 \mathrm{~mm}$, pale - yellow.

Legs yellowish, with spines. Femora I armed with 2 prolateral spines on apical half. Tibia II-IV with 1 prolateral and 1 retrolateral spines on apical half and 1 pr., $1 \mathrm{rt}$. and 2 ventral spines in the middle. Metatarsus II-IV with $1 \mathrm{pr} ., 1 \mathrm{rt}$. and 1 ventral spines in the middle. 


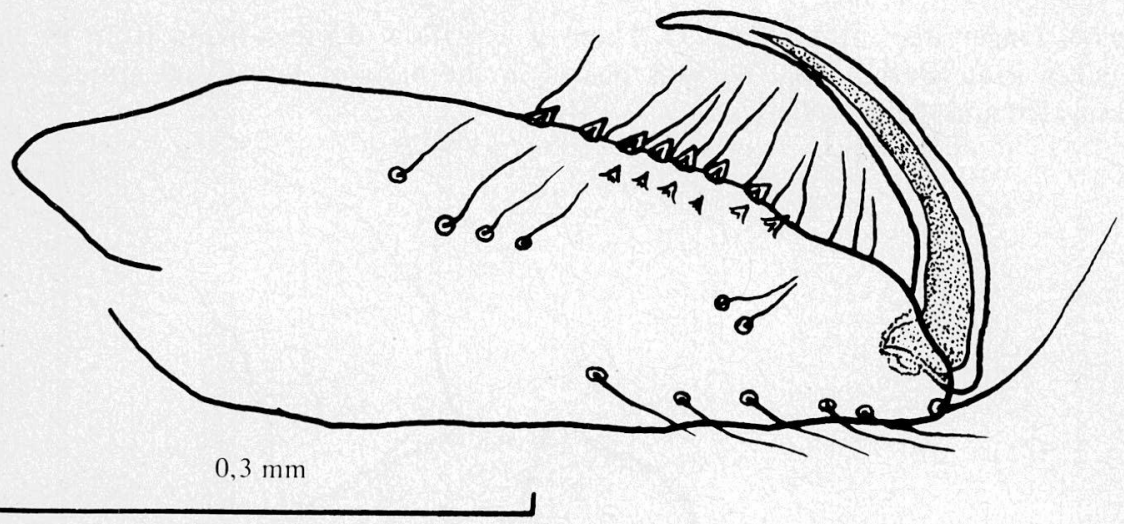

Fig. 2. Left $\delta^{\dagger}$ chelicera, posterior view.

Measurements (in $\mathrm{mm}$ ) of legs:

$\begin{array}{lllllll}\text { Leg } & \mathrm{Fe} & \mathrm{Pt} & \mathrm{Ti} & \mathrm{Mt} & \mathrm{Ta} & \text { Total } \\ \text { I } & 1.48 & 0.18 & & & & \\ \text { II } & 1.25 & 0.18 & 1.20 & 1.00 & 0.56 & 4.19 \\ \text { III } & 1.04 & 0.18 & 0.91 & 0.82 & 0.46 & 3.41 \\ \text { IV } & 1.38 & 0.18 & 1.48 & 1.20 & 0.73 & 4.96\end{array}$

Palpus (fig. $3,4,5$ ): $\mathrm{Fe}-0.45, \mathrm{Pt}-0.18 \mathrm{~mm}, \mathrm{~Tb}-0.28 \mathrm{~mm}$,

$\operatorname{Tr}-0.28 \mathrm{~mm}$. Femora spineless. Patellar spine not very strong. Tibia with a few not very strong spines. Near the top, there is a thicker spot, provided with a strong

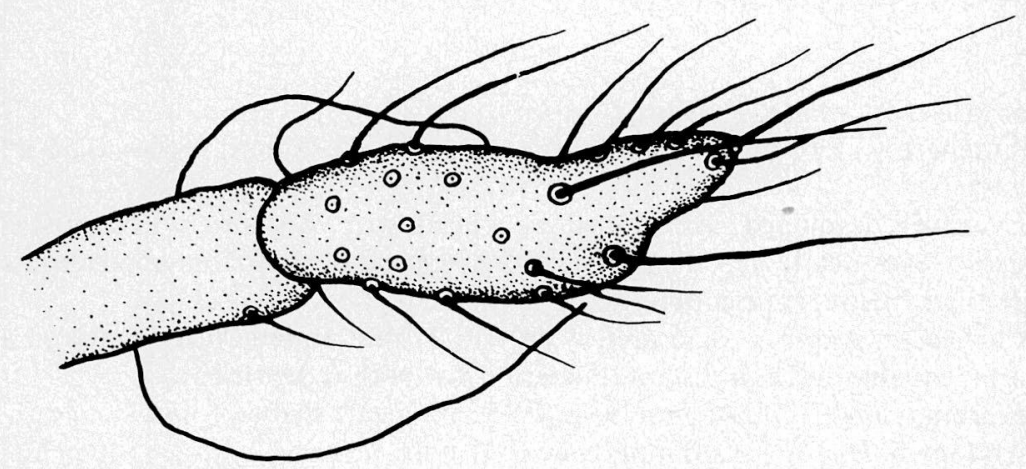

$0,3 \mathrm{~mm}$

Fig. 3. Right ot palp, the thicker spot. 
spine, longer than others (fig. 3). There is a shallow depression, in front of the thicker spot. Bulbus (fig. 4, 5) is placed in the basis of tarsus and armed with elongated and sharpened stylet.

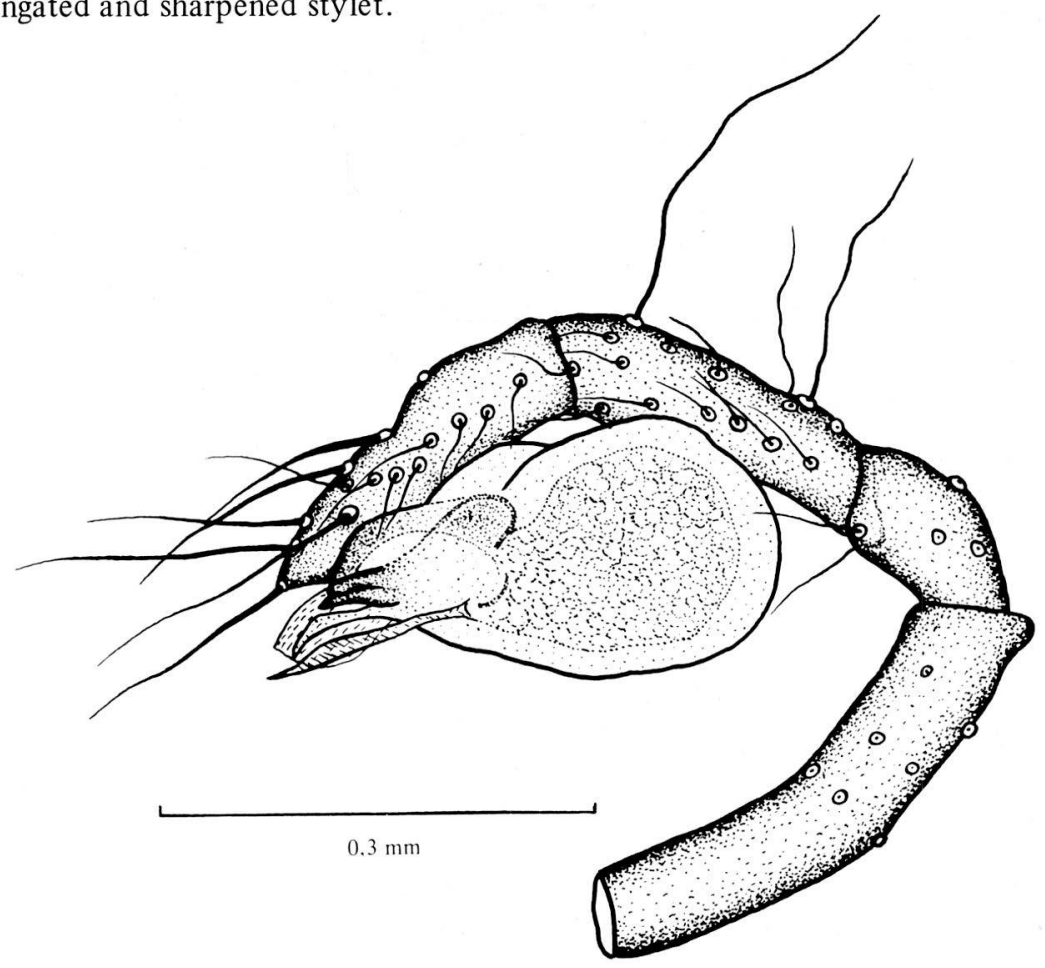

Fig. 4. Left ớ palp, external view.

\section{Description of female}

Total length $-2.10 \mathrm{~mm}$. Cephalothorax, length $-0.73 \mathrm{~mm}$, wide $-0.56 \mathrm{~mm}$, pale yellow.

Eyes well developed, surrounded by a black strip. Anterior eyes almost equable, posterior eyes nearly $1 / 3$ diam. from anteriors and distant from anterior laterals by more than 1 diam. from anteriors.

Chelicerae, length $-0.56 \mathrm{~mm}$, wide $-0.21 \mathrm{~mm}$ armed with 7 teeth on anterior margin, equable and equidistant. Posterior row with 6 denticles.

Sternum, length $-0.45 \mathrm{~mm}$, wide $0.45 \mathrm{~mm}$, heart-shaped form.

Abdomen, length $-1.20 \mathrm{~mm}$, wide $0.91 \mathrm{~mm}$.

Legs yellowish with spines. Femora I armed with 2 pr. and $1 \mathrm{rt}$. in apical half. Tibia III-IV with 1 pr. and $1 \mathrm{rt}$. spines in apical half and 1 pr., $1 \mathrm{rt}$. and 2 ventral spines in the middle. Metatarsus II-IV with 1 pr., $1 \mathrm{rt}$. and 1 ventral spines in the middle. 


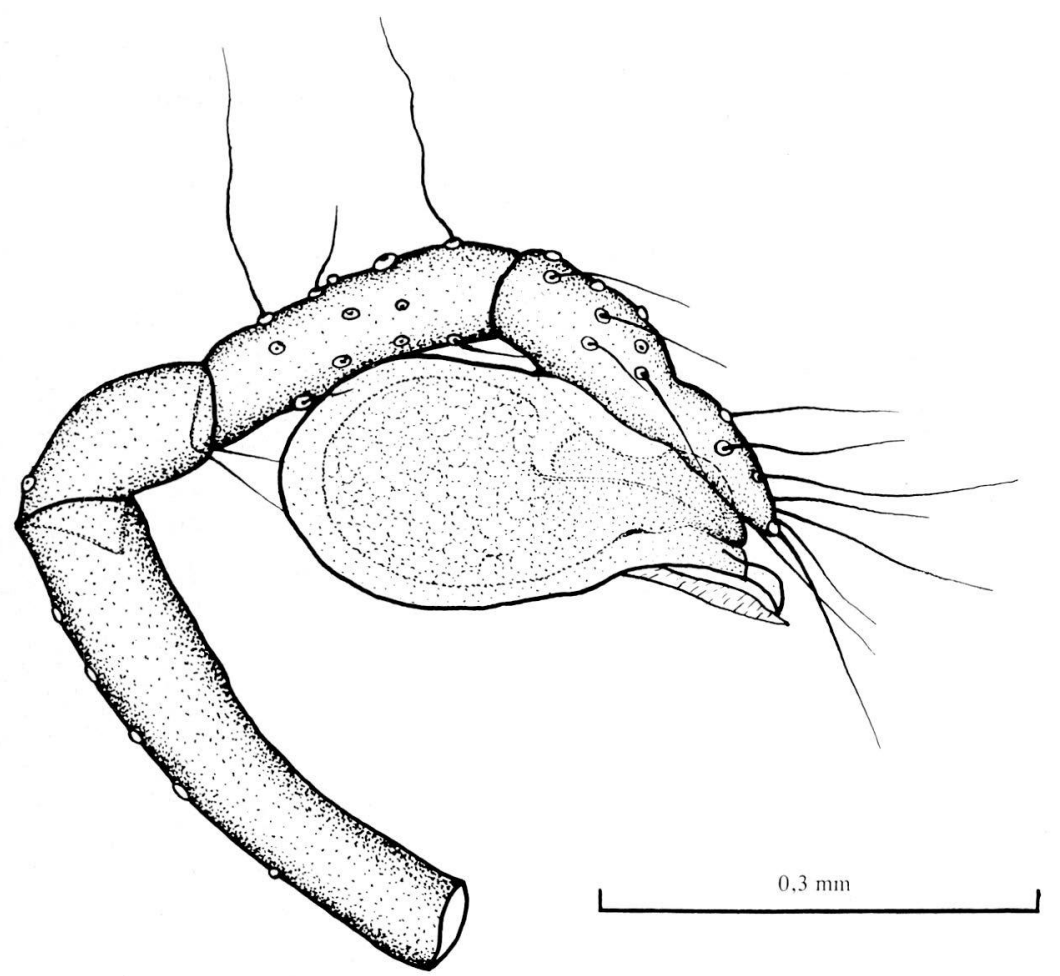

Fig. 5. Left ơ palp, internal view.

Palpus (fig. 6, 7), $\mathrm{Fe}-0.40 \mathrm{~mm}, \mathrm{Pt}-0.14 \mathrm{~mm}, \mathrm{~Tb}-0.28 \mathrm{~mm}, \mathrm{Tr}-0.36$, provided with sickle-shaped claw with a tooth (fig. 7).

Vulva simply built and presented on figure 8.

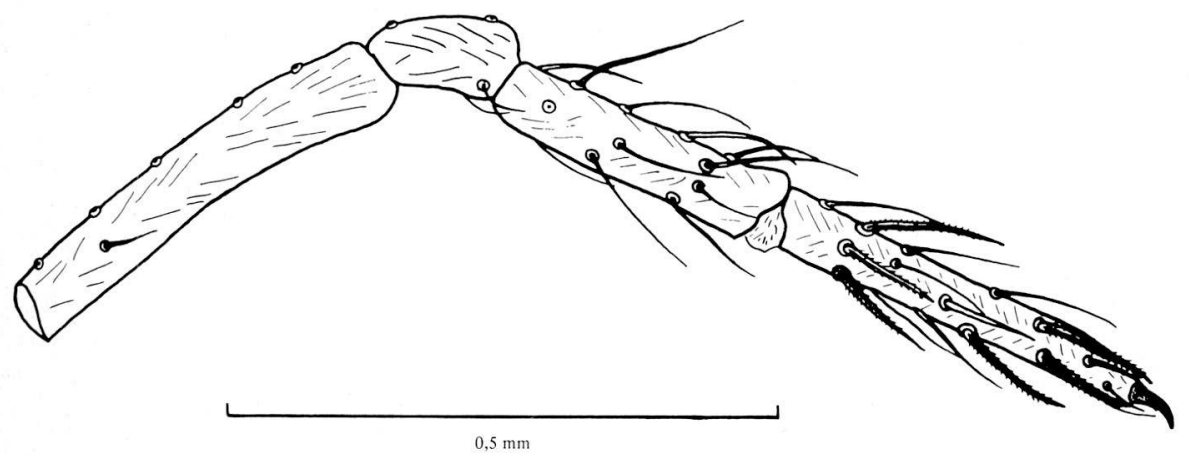

Fig. 6. Female palp, external view. 


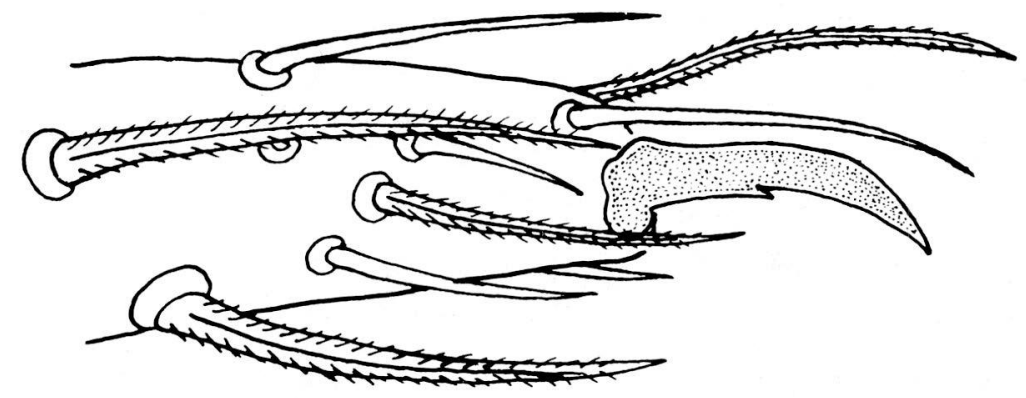

Fig. 7. Female palp, the claw.

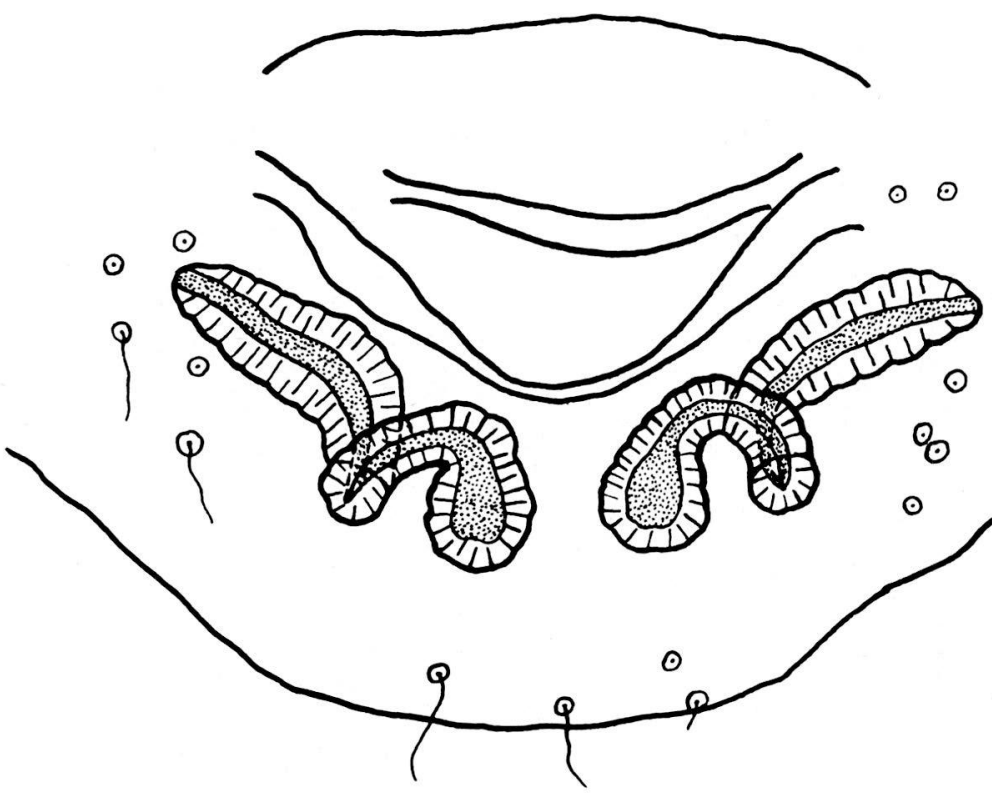

$0,3 \mathrm{~mm}$

Fig. 8. Vulva. 


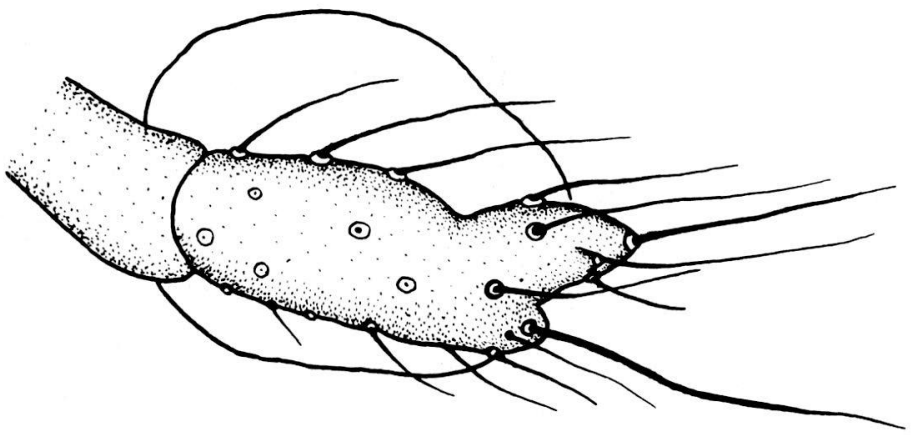

$0,3 \mathrm{~mm}$

Fig. 9. Protoleptoneta italica, right of palp, the thicker spot.

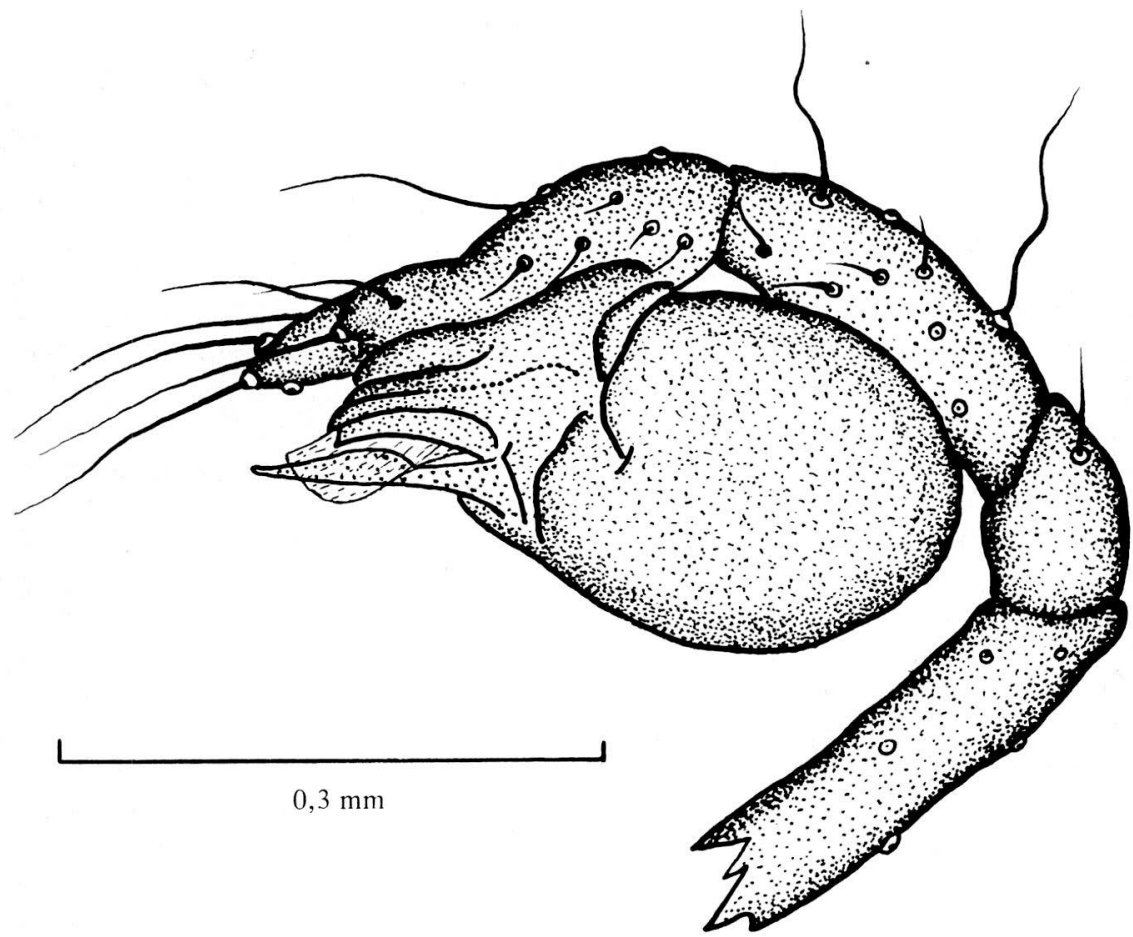

Fig.10. Protoleptoneta italica, left 0 palp, external view. 


\section{MATERIAL AND LOCALITY}

"Besimenna 22" cave near the village of Karlukovo (district of Loveč), 1 male lectotype and 1 female paratype, 19. VIII. 1968; "Dupna mogila" cave near the village of Dolna Bešovica (district of Vraca), 1 t, 7.II.1964 (leg. P. Beron and V. Beškov); "Grebenio" cave near the village of Dolno Osirovo (district of Michailovgrad), 1 o, 16.VI.1970 (leg. P. Beron).

\section{DISCUSSION}

Protoleptoneta bulgarica is related to $P$. italica but both species are readily separated because:

1. Tarsus of $P$. bulgarica is shorter and less depressed. The thicker spot is smaller (fig. 3, 9).

2. Bulbus of $P$. bulgarica is smaller and more extended (fig. 4,10 ).

3. There are differences in the terminal apophysis.

4. There are differences in the vulva (Brignoli in lit. 29.III.1972).

\section{EVOLUTION NOTES}

Fage (1913) expressed two hypotheses about the origin of the genera Leptoneta and Paraleptoneta. According to the first hypothesis, Leptoneta derived from Paraleptoneta on the basis of Protoleptoneta italica. According to the second hypothesis Leptoneta and Paraleptoneta had been developing as two independent phyletic groups. If we accept that Protoleptoneta is the oldest genus, we can complete the second hypothesis and create a new one. The genera Leptoneta and Paraleptoneta had been developing as independent phyletic groups and the origin of the two had been Protoleptoneta.

Of course this hypothesis needs more studies and data to gain full recognition.

Fage (1913) writes, that Leptonetidae had distributed from East to West. Brignoly (1970) claims the reserve, that Paraleptoneta had distributed from West to East. But if we assume that $P$. bulgarica is more primitive than $P$. italica (has a less depressed tarsus and less expressed ectal thickness) this fact confirms the assertion of Fage.

\section{SUMMARY}

A new genus Protoleptoneta (P. bulgarica n. g., n. sp.) is described, which was collected in caves of the Western Balkan mountains - Bulgaria. The new genus unites features of the genera Leptoneta and Paraleptoneta but there are many differences, which divide it from these genera. It differs from Leptoneta as follows: the tarsus of male palp does not possess the characteristic apophysa of Leptoneta; the tarsus is less depressed and does not branch out; the teeth of chelicerae are 
equable and equidistant. It differs from Paraleptoneta as follows: the femora of male palp is spineless; near the top of tarsus, on ectal side, there is a thicker spot, provided with a strong spine longer than others; the tarsus is more depressed. Paraleptoneta italica is placed in the new genus Protoleptoneta. The origin and relationships between the genera Protoleptoneta, Leptoneta and Paraleptoneta are discussed; a hypothesis is that the genera Leptoneta and Paraleptoneta had been developing as independent phyletic groups and the origin of the two had been Protoleptoneta.

\section{RESUME}

Cet article décrit le genre nouveau Protoleptoneta ( $P$. bulgarica n.g., n. sp.). L'Araignée est récoltée dans les grottes du Balkan Occidental - Bulgarie. Le nouveau genre réunit des caractères des genres Leptoneta et Paraleptoneta, mais il y a aussi plusieurs différences qui le séparent de ces genres. Il diffère de Leptoneta par: le tarse du palpe du mâle ne possède pas les apophyses caractéristiques de Leptoneta; le tarse est moins déprimé et n'est pas ramifié, les dents des chélicères sont égales et équidistantes. Il diffère de Paraleptoneta, car les fémurs des palpes du mâle sont privés d'épines; près du sommet du tarse, sur le côté extérieur, il y a une tache épaissie, pourvue d'une épine forte, plus longue que les autres; le tarse est plus déprimé.

Paraleptoneta italica est mise dans le nouveau genre Protoleptoneta. On discute l'origine et les rélations entre les genres Protoleptoneta, Leptoneta et Paraleptoneta; une hypothèse est émise, selon laquelle les genres Leptoneta et Paraleptoneta se sont développés par groupes phylétiques indépendants et que leur base commune aurait été le genre Protoleptoneta.

\section{REFERENCES}

DRENSKY, P. - 1931 - Höhlen - Spinnen aus Bulgarien. Rev. Bulg. Acad. of Sci., XLIX. Sofia.

BRIGNOLI, P. - 1970 - Considerazioni biogeografiche sulla famiglia Leptonetidae (Araneae). Bull. Mus. Hist. nat., 2 ser., 41 (suppl. 1).

BRIGNOLI, P. - 1971 - Note sui cavernicoli italiani. Fragm. Ent., 7 (3).

FAGE L. - 1913 - Etudes sur les araignées cavernicoles II. Revision des Leptonetidae. Arch. de Zool. Exper. et Gen. 5 serie, Tome X.

KOMATSU, T. - 1970 - A new genus and a new species of Japanese spiders (Fascileptoneta n.g. and Sarutana kawasawai n. sp., Leptonetidae). Acta Arach. Osaka 23. 